\section{On the debate about teleology in biology: the notion of "teleological obstacle"}

\section{$O$ debate sobre teleologia na biologia: a noção de "obstáculo teleológico"}

\section{Manuel Gustavo Leitão Ribeiro}

Professor, Instituto de Biologia/Universidade Federal Fluminense. Niterói - RJ - Brasil

ribeiro@vm.uff.br

\section{Ariane Leites Larentis}

Pesquisadora, Escola Nacional de Saúde Pública/Fiocruz. Rio de Janeiro - RJ - Brasil arianelarentis@fiocruz.br

\section{Lúcio Ayres Caldas}

Pesquisador, Laboratório de Microscopia Aplicada às Ciências da Vida/Inmetro. Duque de Caxias - RJ - Brasil

layres-pronametro@inmetro.gov.br

\section{Tomás Coelho Garcia}

Professor, Fundação de Apoio à Escola Técnica do Estado do Rio de Janeiro; doutorando, Instituto de Estudos Sociais e Políticos/

Universidade do Estado do Rio de Janeiro. Rio de Janeiro - RJ - Brasil

tomas_lastro@yahoo.com.br

\section{Letícia Labati Terra}

Professora, Secretaria de Estado de Educação (RJ); professora, Secretaria Municipal de Educação (Rio de Janeiro). Rio de Janeiro - RJ - Brasil letlabati@gmail.com

\section{Marcelo Hawrylak Herbst}

Professor, Instituto de Ciências Exatas/ Universidade Federal Rural do Rio de Janeiro. Seropédica - RJ - Brasil herbst@ufrrj.br

\section{Rodrigo Volcan Almeida}

Professor, Instituto de Química/Universidade Federal do Rio de Janeiro. Rio de Janeiro - RJ - Brasil

volcan@iq.ufr.jbr

Recebido para publicação em julho de 2012.

Aprovado para publicação em julho de 2013.
RIBEIRO, Manuel Gustavo Leitão et al. On the debate about teleology in biology: the notion of "teleological obstacle". História, Ciências, Saúde Manguinhos, Rio de Janeiro, v.22, n.4, out.-dez. 2015, p.1321-1333.

Abstract

Among the epistemological obstacles described by Gaston Bachelard, we contend that unitary and pragmatic knowledge is correlated to the teleological categories of Ernst Mayr and is the basis for prevailing debate on the notion of "function" in biology. Given the proximity of the aspects highlighted by these authors, we propose to associate the role of teleological thinking in biology and the notion of unitary and pragmatic knowledge as an obstacle to scientific knowledge. Thus, teleological thinking persists acting as an epistemological obstacle in biology, according to Bachelardian terminology. Our investigation led us to formulate the "teleological obstacle," which we consider important for the future of biology and possibly other sciences.

Keywords: Gaston Bachelard (18841962); epistemological obstacles; Ernst Mayr (1904-2005); teleology; teleonomy.

\section{Resumo}

Dentre os obstáculos epistemológicos descritos por Gaston Bachelard, propomos que o conhecimento unitário e pragmático se relaciona com as categorias de teleologia propostas por Ernst Mayr e fundamenta as discussões atuais sobre a noção de "função" em biologia. Dada a proximidade dos aspectos salientados por ambos, propomos relacionar o papel do pensamento teleológico na biologia e a noção do conhecimento unitário e pragmático como obstáculo ao conhecimento científico. O pensamento teleológico, portanto, ainda atua como obstáculo epistemológico na biologia, segundo a terminologia bachelardiana. Nossas investigações nos levaram à formulação do "obstáculo teleológico", que entendemos ser importante para o desenvolvimento da biologia e possivelmente para outras ciências.

Palavras-chave: Gaston Bachelard (18841962); obstáculos epistemológicos; Ernst Mayr (1904-2005); teleologia; teleonomia. 


\section{Bachelard and the epistemological obstacle concept}

One of the main contributions made by Gaston Bachelard was the notion of an epistemological obstacle introduced in 1938 in The formation of the scientific mind, and defined by the author as "sluggishness and disturbances" that are intrinsic to the act of knowing. Bachelard contends that it is in terms of obstacles to the very act of cognition that the problem of scientific knowledge should be regarded as a cause of stagnation and even scientific retrogression. He contends that the act of cognition takes place against previous knowledge, thereby destroying poorly defined knowledge (Bachelard, 2002). According to Bachelard, the presence of various epistemological obstacles - be they general or specific - has been detected in various areas of science, which reinforces the need for detailed investigation of both the causes and effects of such obstacles in various areas of scientific knowledge. Although the theory proposed by Bachelard has been used mainly in the investigation of the development of physical sciences, other researchers inspired by his work have demonstrated the relevance of his reflections on the biological sciences as well.

When questioning the theory of epistemological obstacles, several authors (Brousseau, 2002; Galli, Meinardi, 2011) argue that an obstacle is actually knowledge, a concept and not a difficulty or lack of knowledge. This knowledge is able to produce adapted responses to certain problems, but it also produces false answers to other types of problems. It is the kind of knowledge that resists the contradictions with which it is faced, as well as the establishment of better knowledge. It shows resistance to change as a result of its explanatory power, in other words due to its conceptual position in a given knowledge system (Brousseau, 1983, 2002; Galli, Meinardi, 2011) and is characterized by recurrent manifestations. The rejection of this knowledge and the consequent overcoming of the obstacle will lead to new knowledge. According to Brousseau (2002, p.85):

The obstacle is of the same nature as knowledge, with objects, relationships, methods of understanding, predictions, with evidence, forgotten consequences, unexpected ramifications etc. It will resist being rejected and, as it must, it will try to adapt itself locally, to modify itself at the least cost, to optimize itself in a reduced field, following a well known process of accommodation. This is why there must be a sufficient flow of new situations which it cannot assimilate, which will destabilize it, make it ineffective, useless, wrong; which necessitate reconsidering it or rejecting it, forgetting it, cutting it up - up until its final manifestation. Furthermore, the overcoming of an obstacle demands work of the same kind as applying knowledge, that is to say: repeated interaction, dialectics between the student and the object of his/her knowledge. This comment is fundamental to determine the truth of the problem: it is a situation that allows and motivates this dialectic.

Thus, since a unilateral view of epistemological obstacles must be avoided, it should be understood to what extent concepts represent an improvement in the knowledge processes by explaining them. It is necessary to identify at what stage of the scientific knowledge process these concepts begin to hinder the advancement of more precise concepts, which is the main issue dealt with in Bachelard's epistemology, hence its importance.

In The formation of the scientific mind (first published in 1938), Bachelard described the following epistemological obstacles, beyond the pragmatic and unitary obstacle, which will 
be specifically addressed later: (1) the primary experience, (2) general knowledge, (3) verbal obstacle, (4) substantialist and (5) animist obstacles. In the primary experience, the superficial description of the object is enough to understand it: "Indeed, this primary observation brings with it a profusion of images: it is vivid, concrete, natural, and easy. You need only describe it and marvel. And then you think you understand it" (Bachelard, 2002, p.29). General knowledge refers to a tendency of undefined premature generalizations that aim to include the most distinct events in the same concept. The verbal obstacle implies the indiscriminate use of scientific language, words, analogies, images, metaphors, and "jargons." The substantialist obstacle encompasses the identification of only evident, profound or superficial characteristics of the material, as its intrinsic properties, by abstracting its relations. The animist obstacle deals with the introduction of the concept of life in a domain which is foreign to biological sciences. Despite the different kinds of epistemological obstacles listed above, it is important to note that they are polymorphous, i.e. more than one obstacle is commonly present in a scientific text or discourse, or even in a theory (Bulcão, 1981). Among the epistemological obstacles proposed by Bachelard (2002), unitary and pragmatic knowledge, as we aim to demonstrate in this paper, possess a conceptual point of relevance in contemporary biology, and possibly in other sciences as well.

\section{Unitary and pragmatic knowledge as an obstacle to scientific knowledge}

According to Bachelard (2002, p.91), unitary and pragmatic knowledge is directly linked to the influence of philosophy, a vision of the world, in areas of science: "Empirical thought is no longer what is involved here: what we are dealing with is in fact philosophical thought. Here, sweet lethargy halts experience; all questions are stilled in a vast Weltanschauung; all difficulties are resolved through a general view of the world, simply by referring to a general principle of nature." In addition, Bachelard contends that: "It is also often said that science craves unity, that it tends to identify very diverse phenomena, and that it seeks simplicity or economy in principles and also in methods. Contrary to this however, scientific progress is at its clearest when it gives up philosophical factors of easy unification such as the creator's unity of action, nature's unity of plan, or logical unity" (p.26).

We note therefore that, if on one hand unity is linked to a vision of perfection and homogeneity in nature, on the other hand a pragmatic aspect is linked to the utilitarian induction force, namely the tendency to look for a function or an objective to explain a certain phenomenon. Thus, in general, we can say that an obstacle is unitary in the sense that it is a unit of a natural process, as if it had been built by a supreme form of intelligence, and it is pragmatic because all these processes have a purpose, a use, a usefulness, which in general is translated by means of human interpretation. Thus, we can say that, in regard to the unitary and pragmatic obstacle, Bachelard (2002) shows that its influence in the study of a science leads to a finalist and, therefore, teleological concept of natural phenomena.

However, it may be argued that, according to Bachelard (2002), the unitary and pragmatic obstacle does not play an important role. This is evident when it is compared to other obstacles of greater importance in the history of physics and chemistry, the two main sciences on which the author's interest was focused. The parameters of the problem change when we turn to the 
development of biology. Few studies have been made so far that attempt to use the conceptual and instrumental approach proposed by Bachelard in this field, in spite of the debate in recent decades regarding teleology in biology, particularly in relation to interpretations of the Darwinian theory of evolution (Scheffler, 1959; Mayr, 1961, 1974, 1988, 1991, 1992, 2004; Ayala, 1970; Wright, 1972, 1973, 1976; Cummins, 1975, 2002; Boorse, 1976; Woodfield, 1976; Nagel, 1977a, 1977b; Gould, Lewontin, 1979; Gould, 1980; Brandon, 1981; Millikan, 1984; Dawkins, 1986; Jacobs, 1986; Bigelow, Pargetter, 1987; Løvtrup, 1988; Mitchell, 1989; Bedau, 1991; Neander, 1991; Kitcher, 1993; Godfrey-Smith, 1993, 1994; Amundson, Lauder, 1994; Dennett, 1995; Christensen, 1996; Ruse, 2000; Caponi, jan.-jul. 2002; Goldstein, 2002; Sober, 2003; Ferreira, 2003; Chediak, 2006; Junker, 2007; Nunes-Neto, El-Hani, 2009; Perlman, 2010; Martins, 2011; Walsh, 2011; Galli, Meinardi, 2011; Sloan, 2012, to cite some of the numerous publications on the subject).

Galli and Meinardi (2011) have recently identified teleological thinking as an obstacle to learning about a "natural selection evolutionary model." This work is important because it identifies teleology as being implicit in the concepts of "purpose" and "function" in the teaching-learning process of natural selection in biology, indicating that these concepts are obstacles. According to the authors: "The concept of 'obstacle', as used in science didactics, is inspired by the concept of 'epistemological obstacle' suggested by the French philosopher Gaston Bachelard (1938).... When such a thought system competes with a scientific model that we intend to teach (i.e. it can provide an explanation for a particular phenomenon), then it becomes an obstacle" (p.147; emphasis in the original).

However, in our understanding, this concept persists not only in the teaching-learning process, but as part of biological science development as well. When employing Bachelard's epistemological obstacle, we are dealing with a concept in the development process of a science that is not restricted to its teaching. In our experience, students and researchers alike share the same "misconceptions" about integrating the conceptual framework of science. As a result, our aim was to treat the idea of an epistemological obstacle as being more closely associated with the example proposed by Bachelard.

To our knowledge, no author has treated teleology as an epistemological obstacle to making the connection between the development of biology and Bachelardian epistemology. Therefore we intend to contribute to this debate, by outlining its scientific (and philosophical) implications. Based on the proposal of a "teleological obstacle," we intend to contribute to this debate by providing a new perspective: unlike traditional authors involved in this debate, we do not view teleology as being something outside biology, nor as part of the conceptual framework of this science. Many of the proponents who see teleology as an intrinsic domain of biology, contend, for example, that Darwinian theory discovered a way to "naturalize" teleology by means of adaptive stories (cf. Wright, 1976; Nagel, 1977a, 1977b; Bedau, 1991; Ruse, 2000). We, however, understand teleology as being an intrinsic element of the development of biology, which arises as a consequence of the historical conditions of its emergence as a science and as one that acts dialectically as an obstacle to its development. In this sense, biology itself must discover a way to deal with this obstacle and attempt to overcome it in order to develop more precise scientific concepts in this field. In this manner, we sought to place the debate within this science, without exteriorizing it. 
We maintain that the greatest advance made in addressing teleology in the field of biology was made by Ernst Mayr, who investigated the exploitation of the discipline by using that philosophical category. In doing so, it was possible for Mayr to "clear the field" of the concept of teleology, making it possible to identify what teleology really means in biology, while posing as science - thereby constituting the "teleological obstacle," as we propose - so that it can be overcome. As Mayr (2004, p.49) states, clarifying the concept of teleology permits the scientific identification of a specific biological process, its causes, deployments and relations, propelling the scientific concepts that define biology as a "genuine science free from any occult properties." The theoretical position that maintains that teleology is intrinsic to the domain of biology enables the transfer of ideological elements to biology, instead of clearly tackling the (false) needs of these elements in the development of this area of science.

In this context, there is a relative accumulation of critical-theoretical positioning regarding the influence of teleology in the creation of concepts within biology, clearly dealt with in Ernst Mayr's work, which can be analyzed based on a Bachelardian perspective.

\section{Teleology according to Ernst Mayr}

For Ernst Mayr, one of the greatest representatives of twentieth century evolutionary theory, the so-called "Darwin of the twentieth century" (Junker, 2007), teleology is considered as the ideology that has most influenced biology: "Perhaps no other ideology has influenced biology more profoundly than teleological thinking" (Mayr, 2004, p.39).

In his studies on teleology, although the term "epistemological obstacle" is not used, Mayr $(1992,2004)$ attempts to distinguish between the philosophical use of what was conventionally called teleology and the current developments in biology: "The scientific study of all natural phenomena formerly designated as teleological has deprived the subject teleology of its former mystery" (Mayr, 2004, p.49).

For Mayr, there are no truly teleological natural phenomena. For phenomena erroneously classified as such, he proposed categories related to biology in order to distinguish them from finalist processes, which he included in the category of cosmic teleology. The five categories proposed by Mayr (2004), which had until then been grouped together under the general term of teleology, are: (1) teleomatic processes, in which there is a final term, but not an intent, e.g. the effects of gravity (a falling rock); (2) teleonomic processes, in which there is an orientation resulting from a program. In this case, the goal of the activity does not lie in the future, but is encoded in the program, e.g. the genetic material; (3) the purposeful behavior of animals; (4) adaptive characteristics, such as a posteriori results, and not the search for an a priori goal, and; (5) cosmic teleology, in which the authentic finalist process is evoked, i.e. guided by a superior force.

By listing these categories, Mayr seeks to distinguish between apparent teleological processes and the truly finalist ones included in category 5 . As for the other categories ( 1 to 4 ), they are developments of biology and their relationship to teleological thinking represents the epistemological obstacle, which is the subject-matter of this paper. ${ }^{1}$ It is possible that, initially, several biologists have used teleological arguments in the elaboration of such categories. However, Mayr clearly rejects the need to refer to teleological arguments: "It is now 
realized that four of the five phenomena traditionally called teleological can be completely explained by science, while the fifth one, cosmic teleology, does not exist. This clarification of the concept of teleology has greatly contributed to the conclusion that biology is a genuine science without any occult properties ... There is no cosmic teleology; there is no trend in the world toward progress or perfection" (Mayr, 2004, p.49, 60).

And: "Cosmic teleology must be rejected by science" (Mayr, 1991, p.131). As accurately stated by Junker (2007, p.10): "For Mayr invalid 'occult' and metaphysical concepts in biology ranged from the anima and vis vitalis to teleological causations (causa finalis) and supernatural (religious) explanations. These ideas have in common that they cannot be proven scientifically and are in conflict with the laws of the physical sciences."

The notion of teleonomy (an orientation resulting from a program, but without the existence of an a priori purpose or goal) is also used by Jacques Monod (1970), in Le hasard et la nécessité (Chance and necessity), as the property that distinguishes living things from "all other structures of all systems present in the universe" (p.22; our translation). It should be noted that it was only with the advancement of knowledge on genetics and its compatibility with Darwin's theory - a process commonly known as Modern Synthesis, Evolutionary Synthesis or Synthetic Theory of Evolution - that it became possible to establish the material basis of the occurrence of natural selection. This made it possible to eliminate non-natural causes and the need to evoke supernatural forces from this field in order to explain evolution (breaking away from concepts such as an orthogenetic force directing the evolutionary process, a metaphysic force which evoked a finalist principle, which were popular until the 1930s). ${ }^{2}$

\section{A Bachelardian reading of Mayr: the notion of teleological obstacle}

According to Bachelard (2002), for a pre-scientific mind, truth and usefulness are associated, since unitary and pragmatic knowledge cannot conceive a phenomenon that is not "useful" in nature. Bachelard warns us of the dangers of finalist explanations and the philosophical exploitation of science:

Thus, truth must be coupled with usefulness. Truth that has no function is a mutilated truth. And when usefulness has been discerned, the real function of truth has been found. However, these utilitarian views are aberrations. The dangers of finalist explanations have so often been shown that there is no need to place any further emphasis here on this obstacle to a truly objective culture. We simply thought it necessary to point out that this obstacle was particularly dangerous in the eighteenth century. This was because the literary and philosophical exploitation of science was still very easy at this time (p.101).

Mayr (2004) argues that there is no support for teleology in Darwin's theory presented in The origin of species (although in correspondence, particularly in his later years, he was sometimes careless in his use of language); that Darwin was a teleologist at the beginning of his studies, but abandoned teleology after adopting natural selection as a mechanism of evolutionary change. However, after Darwin established the principle of natural selection, this process was widely interpreted as being teleological (both by his supporters and his 
opponents); evolution was often considered a teleological process because it would lead to "improvement" or "progress." Nevertheless, according to Mayr (2004, p.62), this view is no longer reasonable when one considers the variational nature of Darwinian evolution, which has no end goal, and (re)starts with each new generation. Natural selection often leads to "fatal dead ends," resulting in an "irregular zigzag movement of the evolutionary change."

As discussed before, when we correlate the proposals supported by Bachelard and Mayr, we come to the conclusion that teleological thinking is one of the main epistemological obstacles to the construction of scientific knowledge in biological sciences. However, it is impossible to predict which direction scientific knowledge will take. The finalist or teleological view of the world sees a tendency toward perfection, or improvement, in all phenomena. In biology, it is possible to see that this view is based on the misconception that evolution equals progress and that all parts of a system (e.g. the different organs of a multicellular organism) exist and play an appropriate part in achieving the perfect harmony and functioning of the whole. With respect to this view, it seems appropriate to quote Mayr (2004, p.62-63), if only to deconstruct the above misconception:

To be sure, natural selection is an optimization process, but it has no definite goal, and, considering the number of constraints and the frequency of chance events, it would be most misleading to call it teleological. Nor is any improvement in adaptation a teleological process, because whether a given evolutionary change qualifies as a contribution to adaptedness is strictly a post hoc decision. ... Natural selection deals with properties of individuals of a given generation; it simply does not have any longrange goal, even though this may seem so when one looks backward over a long series of generations.

In view of the fact that the natural selection process is not teleological, as demonstrated by Mayr, and that teleological thinking persists in biology and can function as an epistemological obstacle, and because the unitary and pragmatic knowledge that we have acquired from Bachelard is not an appropriate component of biological problems (which include the question of "functions" in this area of science, as discussed in the following section), our research team proposed to adopt the concept of "teleological obstacles."

\section{Teleology and the concept of biological "function"}

According to Mayr (1961), if we conceive of biology as being divided into two great fields of science - functional biology and evolutionary biology - then explanations of biological phenomena could refer respectively to immediate or proximate causes (physicochemical) and distant causes, ultimately resulting from a genetic program that is the result of random events occurring during the evolutionary process. Teleological interpretations may arise when one fails to notice that the "functions" performed by an organ or structure of a given organism have their origins in evolutionary causes. According to Mayr (2004), in the development of biology, the influence of teleological thinking has led many authors to simply shift the problem of "teleological propositions" to the field of "functional propositions," in other words to use the functions of a system to explain its objective or its "final cause". Final cause has been defined as "the cause responsible for the orderly reaching of a preconceived 
ultimate goal" (Mayr, 1961, p.1503). In fact, this question was of such importance to Mayr that he suggested using the term "biological role," instead of "function" (Mayr, 2004, p.48).

The "structure-function" approach is very common among researchers in biology, i.e. the notion that if a given structure (molecule, organelle, organ etc.) exists, it must have a function; or even that it exists only by virtue of being functional. Some authors, for example, argue that vestigial organs (like the appendix, ear muscles, the coccyx, among others in the human body) cannot be considered proof of evolution theory (contradicting what Darwin argued in The origin of species regarding "rudimentary organs"), since one cannot state that they do not have a function, but that such a function has not been discovered (Scadding, 1981) or that they represent the degeneration of a functional structure, not the evolution of a new one (Huse, 1983).

However, these concepts imply the permanence of intentionality in this field of science, which, according to Bachelard (2002), may hinder future progress of scientific thought in regard to that system by disrupting scientific reasoning, as well as hampering further studies. Once the link is found that leads to unity and usefulness, the knowledge process is finalized, hence "the danger of explaining things by the 'unity' of nature and the 'usefulness' of natural phenomena" (p.31; emphasis in the original). Ultimately, when scientific research is only directed towards finding the function of a given structure, its discovery may to some extent prevent the construction of more advanced or precise knowledge about that structure and its relationship to others.

As stated previously, this investigation takes a different direction in functional and evolutionary biology. In evolutionary biology, the search for "why" naturally considers a historical narrative in an attempt to understand the origins of a biological structure or organic diversity in an ecosystem, for instance. This field of biology often resorts to natural selection to explain the permanence of a particular behavior or biological structure based on the "function" performed by this feature in the organism. According to Cummins (2002), researchers who use this kind of explanation are "neoteleologists," as they consider that the existence of a biological characteristic is due to its function and not to its history of development (pressures experienced during the evolutionary process). In "neoteleology," natural selection merely replaces the figure of a supreme creator or a hidden force capable of directing evolution, giving rise to a certain characteristic due to the function it will have in a given organism. Cummins and his notion of neotelelology were criticized for several reasons. In our view, one of the most relevant criticisms is that the author based his hypothesis on the (false) premise that the evolutionary process occurs mainly through gradual change, disregarding events that may actually lead to a functional novelty (cf. El-Hani, Nunes-Neto, 2009; Nunes-Neto, El-Hani, 2009). We contend that one of the best alternatives currently available to avoid any misunderstanding of a biological phenomena was presented by Mayr (2004), when he proposed four categories for biological processes (as listed above), which have been mistakenly classified as teleological. The contribution made by Mayr is crucial to this debate, especially as it is usually minimized or misunderstood by different authors in the field of biological philosophy. Instead of "naturalizing" teleology, Mayr demonstrates that several so-called teleological processes can be explained without the artifice of teleology. 
According to Mayr (2004, p.61), "none of the four recognized teleological processes works backward from an unknown future goal; there is no backward causation."

Among the categories listed by Mayr, we should stress that category (4), adaptive characteristics, results from tensions related to the concept of weak neoteleology, as described by Cummins in 2002 (reviewed by Nunes-Neto, El-Hani, 2009) to emphasize that no evidence can be selected based on its functions. Evolutionary changes, which are apparently teleological and referred to as "adaptations," are the result of variational evolution. As anti-teleological thinking par excellence, Darwinism abolishes the need for final causes, contrasting harmony and perfect adaptation to the conditions of existence, with imperfection, disorder and randomness. Thus, natural selection is reaffirmed as a directionless process, which means that the notion of adaptation is an inappropriate (or vulgarized) term to explain the essence of Darwinian theory.

As Mayr (2004, p.63) had predicted, even in recent years, evolution has been seen from a teleological perspective: "Alas, some authors even in the most recent literature seem to endow evolution with a teleological capacity." Investigations carried out by our own and other research groups have found that teleological concepts interfere with the scientific understanding and practice of students (Richardson, 1990; Van Dijk, Reydon, 2010; Galli, Meinardi, 2011; Larentis et al., 2012), and even of professors and researchers in the field of biology and correlated areas (Larentis et al., 2011). Several authors make concessions to teleology in discussing whether functional explanations are embedded in teleological conceptions. It is quite common for authors to advocate that teleological explanations are part of the field of biology, instead of identifying possible teleological explanations and breaking away from them and developing concepts that are closer to a scientific conception in the strong sense, supporting the advancement of scientific knowledge. Teleological concepts in biology may constitute epistemological obstacles in the construction of knowledge regarding this science and even obstacles to learning and understanding of concepts by students and teachers (Galli, Meinardi, 2011). Scientific practice involves overcoming obstacles through the production of new scientific concepts; also, the presence of a teleological language must be viewed as a limitation to be overcome. Mayr (1974, p.93) draws our attention to the implications that the presence of concepts and teleological language have in the field of science: "Teleological statements and explanations imply the endorsement of unverifiable theological or metaphysical doctrines in science."

Teleological language seemed to represent objectionable anthropomorphism. The use of terms like purposive or goal-directed seemed to imply the transfer of human qualities, such as intent, purpose, planning, deliberation, or consciousness, to organic structures and to subhuman forms of life. ... As a result of these and other objections, teleological explanations were widely believed to be a form of obscurantism, an evasion of the need for a causal explanation. Indeed some authors went so far as to make statements such as 'Teleological notions are among the main obstacles to theory formation in biology' (Lagerspetz, 1959, p.65). Yet, biologists insisted on continuing to use teleological language (Mayr, 1988, p.40-41; emphasis in the original).

Teleological thinking conceals a (mistaken) linear concept of evolution, an evolutionary change endowed with an (unconfessed) functional essence. Terms like "function" and 
"purpose" (or "objective") can be replaced by terms such as "consequence" or "result," indicating an absence of direction. Evolutionary linearity and functionality lead to the underlying - and mistaken - notion that in the process of natural selection the survival of the species is more important than its elimination. The non-teleological, non-purposive characteristic of the theory of natural selection was brilliantly summarized by Stephen Jay Gould (1977, p.90): "Extinction is the fate of most species."

\section{Final considerations}

Given that Darwin elaborated concepts which made it possible to overcome the boundaries of the finalist conception (Martins, 2011), thereby establishing biology as a genuine and autonomous scientific field of study, teleological thinking is incompatible with a scientific view of biological processes. Taking into consideration current knowledge of evolutionary processes, teleological concepts act as obstacles to scientific advances, which means that there is no scientific basis for the permanence of teleological thinking in biology. As argued by Mayr (1974), teleology endorses metaphysical doctrines in science. The debate on the use of teleological explanations in biology, particularly in evolutionary biology, remains current, showing the strong presence of teleological thinking. Hence, the need to characterize what we have called a "teleological obstacle," since in order to overcome an obstacle it is first necessary to identify it by the construction/accuracy of scientific concepts.

In biology, efforts are made to pursue an ideology that unites all elements, irrespective of the problem and complexity of the phenomenon in which they are inserted, attributing these with an a priori character. The main stronghold of teleological thinking in evolutionary biology is the notion of "function." The consequence may be the arising/strengthening of obstacles to the advancement of biological knowledge about a given structure and its relationship to others. The proposal to replace the term "function" for "biological role," as suggested by Mayr, may not solve the teleological obstacle issue, but is an attempt to safeguard the scientific argument, without concessions or the need to consider teleological thinking as being an intrinsic and therefore necessary process in evolutionary biology.

A teleological obstacle may also be important in other fields of science, where phenomena are irreversibly time-dependant, as is the case in cosmology, history etc. The study of the obstacle in fields of science other than biology, as specifically discussed in this paper, will therefore make it possible to provide a more precise conceptualization of the obstacle and thereby make an important contribution to the epistemology of the science.

\section{ACKNOWLEDGMENTS}

The National School for Public Health (Escola Nacional de Saúde Pública - Ensp/Fiocruz) partially supported this work. The authors wish to thank those who participated in the symposium entitled: "Materialismo e evolucionismo: a origem do homem da perspectiva materialista (Materialism and Evolutionism: the Origin of Man from a Materialist Perspective)," held at the Institute for Philosophy and Human Sciences at Unicamp (Instituto de Filosofia e Ciências Humanas/Unicamp) between lst and 2nd September, 2009, for their views and suggestions, with our special thanks also to Prof. Maurício Vieira Martins/UFF. We would also like to thank professors Lucia Moreira Campos Paiva and Giberto Barbosa Domont, from the Department of Biochemistry/ UFRJ, and all those who participated in the regular study groups organized by the Interdisciplinary and Inter-institutional Epistemology Study Group (Grupo Interinstitucional e Interdisciplinar de Estudos em Epistemologia) (GI2E2, www.epistemologia.ufrj.br) for their very productive discussions. 


\title{
NOTES
}

\begin{abstract}
${ }^{1}$ In this paper, we have decided not to address the explicit influence of religious thought in biology, since, even though its existence cannot be denied, teleological thinking cannot be merely limited to religious influence, but should be addressed in a debate within the science of biology per se. Religious thinking is more easily classifiable as an ideology, as a non-scientific element. However, teleological conceptions (for example the idea that teleology is intrinsic to the field of biology), and therefore apparently a scientific matter, in fact, bring back the idea of "purpose" to the scientific field, with more sophisticated arguments and are therefore more difficult to overcome. We therefore decided to treat this problem under the heading of "teleological obstacle."
\end{abstract}

${ }^{2}$ This process of making Darwin's theory compatible with genetics and the contributions of systematics and paleontology began in the 1920s with Ronald Fisher, J.B.S Haldane and Sewall Wright. In the 1940s, the paleontologist George Gaylord Simpson, the biologist Ernst Mayr (Junker, 2007) and the geneticist Theodosius Dobzhansky ("Nothing in biology makes sense except in the light of evolution", 1973) were crucial for establishing modern evolutionary theory. The term modern synthesis or evolutionary synthesis was introduced by Julian Huxley in his book Evolution: the Modern Synthesis (1942). Ernst Mayr, in What makes biology unique? (2004), argues that the synthetic theory of evolution developed in the 1940s "is best simply referred to as Darwinism ... because it encompasses the essentials of Darwin's original concept" (p.130).

\section{REFERENCES}

AMUNDSON, Ron; LAUDER, George V. Function without purpose: the uses of causal role function in evolutionary biology. Biology and Philosophy, v.9, n.4, p.443-469. 1994.

AYALA, Francisco J.

Teleological explanations in evolutionary biology. Philosophy of Science, v.37, n.1, p.1-15. 1970.

BACHELARD, Gaston.

The formation of the scientific mind: a contribution to a psychoanalysis of objective knowledge. Manchester: Clinamen. 2002.

BEDAU, Mark.

Can biological teleology be naturalized? The Journal of Philosophy, v.88, n.11, p.647-655. 1991.

BIGELOW, John; PARGETTER, Robert.

Functions. The Journal of Philosophy, v.84, n.4, p.181-196. 1987.

BOORSE, Christopher.

Wright on functions. The Philosophical Review, v.85, n.1, p.70-86. 1976.

BRANDON, Robert N.

Biological teleology: questions and explanations. Studies in History and Philosophy of Science, v.12, n.2, p.91-105. 1981.

BROUSSEAU, Guy.

Epistemological obstacles and problems in mathematics. In: Balacheff, Nicolas et al. (Ed.). Theory of didactical situations in mathematics. New York: Kluwer Academic Publishers. p.79-98. 2002.

BROUSSEAU, Guy.

Les obstacles épistémologiques et les problèmes en mathématiques. Recherches en Didactique des Mathématiques, v.4, n.2, p.165-198. 1983.
BULCÃO, Marly.

O racionalismo da ciência contemporânea: uma análise da epistemologia de Gaston Bachelard. Rio de Janeiro: Antares. 1981.

CAPONI, Gustavo.

Selective explanation and functional

explanation: teleology in contemporary biology. Episteme, n.14, p.57-88. jan.-jul. 2002.

CHEDIAK, Karla de Almeida.

Analysis of the concept of function from a historical point of view. Filosofia e História da Biologia, v.1, p.161-174. 2006.

CHRISTENSEN, Wayne.

A complex systems theory of teleology. Biology and Philosophy, v.11, n.3, p.301-320. 1996.

CUMMINS, Robert.

Neo-teleology. In: Ariew, André; Cummins, Robert; Perlman, Mark (Ed.). Functions: new essays in the philosophy of psychology and biology. Oxford: Oxford University Press. p.157172. 2002.

CUMMINS, Robert.

Functional analysis. The Journal of Philosophy, v.72, n.20, p.741-765. 1975.

DAWKINS, Richard.

The blind watchmaker: why the evidence of evolution reveals a universe without design. New York: W.W. Norton. 1986.

DENNETT, Daniel C.

Darwin's dangerous idea: evolution and the meanings of life. New York: Simon \& Schuster. 1995.

DOBZHANSKY, Theodosius.

Nothing in biology makes sense except in the 
light of evolution. American Biology Teacher, v.35, p.125-129. 1973.

EL-HANI, Charbel Niño; NUNES-NETO, Nei Freitas. Function in biology: etiological and organizational perspectives. Acta Biológica Colombiana, v.14, supl.1, p.111-132. 2009.

FERREIRA, Marcelo Alves. Teleology in contemporary biology. Scientiae Studia, v.1, n.2, p.183-193. 2003.

GALLI, Leonardo Martín González; MEINARDI, Elsa N.

The role of teleological thinking in learning the darwinian model of evolution. Evolution: Education and Outreach, v.4, n.1, p.145-152. 2011.

GODFREY-SMITH, Peter.

A modern history theory of functions. Noûs, v.28, n.3, p.344-362. 1994.

GODFREY-SMITH, Peter.

Functions: consensus without unity. Pacific Philosophical Quarterly, v.74, n.3, p.196-208. 1993.

GOLDSTEIN, Adam.

Nature's purposes: analyses of function and design in biology. Australasian Journal of Philosophy, v.80, n.1, p.126-128. 2002.

GOULD, Stephen Jay.

Shades of Lamarck. In: Gould, Stephen Jay. The panda's thumb: more reflections in natural history. New York: W.W. Norton. p.76-84. 1980.

GOULD, Stephen Jay.

Ever since Darwin: reflections in natural history. New York: W.W. Norton. 1977.

GOULD, Stephen Jay; LEWONTIN, Richard Charles.

The spandrels of San Marco and the Panglossian paradigm: a critique of the adaptationist programme. Proceedings of the Royal Society of London, Series B: Biological Sciences, v.205, n.1161, p.581-598. 1979.

HUSE, Scott M.

The collapse of evolution. Grand Rapids: Baker Books. 1983.

HUXLEY, Julian S.

Evolution: the Modern synthesis. London: Allen \& Unwin. 1942.

JACOBS, Jonathan.

Teleology and reduction in biology. Biology and Philosophy, v.1, n.4, p.389-399. 1986.

JUNKER, Thomas.

Ernst Mayr (1904-2005) and the new philosophy of biology. Journal for General Philosophy of Science, v.38, n.1, p.1-17. 2007.
KITCHER, Philip.

Function and design. Midwest Studies in Philosophy, v.18, n.1, p.379-397. 1993.

LARENTIS, Ariane Leites et al.

Epistemological obstacles amongst graduate students in biochemistry. Ciências \& Cognição/ Science and Cognition, v.17, n.2, p.76-97. 2012.

LARENTIS, Ariane Leites et al.

Vitalism and teleology in the Brazilian biochemical research community: a case study. In: Encontro Nacional de Pesquisadores em Ensino de Ciências, 8; Congreso Iberoamericano de Investigación en Enseñanza de las Ciencias, Campinas, Associação Brasileira de Pesquisa em Educação em Ciências/Unicamp. p.1-12. 2011.

LØVTRUP, Søren.

Design, purpose and function in evolution: meditations on a classical problem. Environmental Biology of Fishes, v.22, n.4, p.241-247. 1988.

MARTINS, Maurício Vieira.

Consequências filosóficas da polêmica de Darwin com o pensamento religioso. In: Moraes, João Quartim de (Org.). Materialismo e evolucionismo 2: a origem do homem. Campinas: Unicamp/ Centro de Lógica, Epistemologia e História da Ciência. p.59-89. 2011.

MAYR, Ernst.

What makes biology unique? Considerations on the autonomy of a scientific discipline. New York: Cambridge University Press. 2004.

MAYR, Ernst.

The idea of teleology. Journal of the History of Ideas, v.53, n.1, p.117-135. 1992.

MAYR, Ernst.

The ideological resistance to Darwin's theory of natural selection. Proceedings of the American Philosophical Society, v.135, n.2, p.123-139. 1991.

MAYR, Ernst.

The multiple meanings of teleological. In: Toward a new philosophy of biology: observations of an evolutionist. Cambridge: Harvard University Press. p.38-66. 1988.

MAYR, Ernst.

Teleological and teleonomic: a new analysis. Boston Studies in the Philosophy of Science, v.14, p.91-117. 1974.

MAYR, Ernst.

Cause and effect in biology: kinds of causes, predictability, and teleology are viewed by a practicing biologist. Science, v.134, n.3489, p.1501-1506. 1961.

MILLIKAN, Ruth Garrett.

Language, thought, and other biological categories. Cambridge: The MIT Press. 1984. 
MITCHELL, Sandra D.

The causal background of functional explanation. International Studies in the Philosophy of Science, v.3, n.2, p.213-229. 1989.

MONOD, Jacques.

Le hasard et la nécessité: essai sur la philosphie naturelle de la biologie moderne. Paris: Seuil. 1970.

NAGEL, Ernest.

Teleology revisited: goal-directed processes in biology. The Journal of Philosophy, v.74, n.5, p.261-279. 1977a.

NAGEL, Ernest.

Teleology revisited: functional explanations in biology. The Journal of Philosophy, v.74, n.5, p.280-301. 1977b.

NEANDER, Karen.

The teleological notion of "function". Australasian Journal of Philosophy, v.69, n.4, p.454-468. 1991.

NUNES-NETO, Nei Freitas; EL-HANI, Charbel Niño.

O que é função? Debates na filosofia da biologia contemporânea. Scientiae Studia, v.7, n.3, p.353401. 2009.

PERLMAN, Mark.

The modern philosophical resurrection of teleology. In: Rosenberg, Alexander; Arp, Robert (Ed.). Philosophy of biology: an anthology.

Chichester: John Wiley \& Sons. p.149-163. 2010.

RICHARDSON, Daniel R.

A survey of students' notions of body function as teleologic or mechanistic. Advances in Physiology Education, v.258, n.6, part 3, p.S8-S10. 1990.

RUSE, Michael.

Teleology: yesterday, today, and tomorrow? Studies in History and Philosophy of Science Part C, v.31, n.1, p.213-232. 2000.
SCADDING, Steven R.

Do "vestigial organs" provide evidence for evolution? Evolutionary Theory, v.5, p.173-176. 1981.

SCHEFFLER, Israel.

Thoughts on teleology. The British Journal for the Philosophy of Science, v.9, n.36, p.265-284. 1959.

SLOAN, Phillip R.

How was teleology eliminated in early molecular biology? Studies in History and Philosophy of Biological and Biomedical Sciences, v.43, n.1, p.140-151. 2012.

SOBER, Elliott.

Philosophy of biology. In: Bunnin, Nicholas; Tsui-James, Eric P. (Ed.). The Blackwell companion to philosophy. Oxford: Blackwell. p.317-344. 2003.

VAN DIJK, Esther M.; REYDON, Thomas A.C. A conceptual analysis of evolutionary theory for teacher education. Science \& Education, v.19, n.68, p.655-677. 2010.

WALSH, Denis.

Mechanism and purpose: a case for natural teleology. Studies in History and Philosophy of Science Part C, v.43, n.1, p.1-9. 2011.

WOODFIELD, Andrew.

Teleology. Cambridge: Cambridge University Press. 1976.

WRIGHT, Larry.

Teleological explanations: an etiological analysis of goals and functions. Berkeley: University of California Press. 1976.

WRIGHT, Larry.

Functions. The Philosophical Review, v.82, n.2, p.139-168. 1973.

WRIGHT, Larry.

Explanation and teleology. Philosophy of Science, v.39, n.2, p.204-218. 1972. 